\title{
Biophysical effects on the interannual variation in carbon dioxide exchange of an alpine meadow on the Tibetan Plateau
}

\author{
Lei Wang ${ }^{1}$, Huizhi Liu ${ }^{1}$, Jihua $\mathrm{Sun}^{2}$, and Yaping Shao ${ }^{3}$ \\ ${ }^{1}$ LAPC, Institute of Atmospheric Physics, Chinese Academy of Sciences, Beijing 100029, China \\ ${ }^{2}$ Meteorological Observatory of Yunnan Province, Kunming 650034, China \\ ${ }^{3}$ Institute for Geophysics and Meteorology, University of Cologne, Cologne, 50937, Germany \\ Correspondence to: Huizhi Liu (huizhil@mail.iap.ac.cn)
}

Received: 29 November 2016 - Discussion started: 23 December 2016

Revised: 17 March 2017 - Accepted: 27 March 2017 - Published: 20 April 2017

\begin{abstract}
Eddy covariance measurements from 2012 to 2015 were used to investigate the interannual variation in carbon dioxide exchange and its control over an alpine meadow on the south-east margin of the Tibetan Plateau. The annual net ecosystem exchange (NEE) in the 4 years from 2012 to 2015 was $-114.2,-158.5,-159.9$ and $-212.6 \mathrm{~g} \mathrm{C}^{-2} \mathrm{yr}^{-1}$, and generally decreased with the mean annual air temperature (MAT). An exception occurred in 2014, which had the highest MAT. This was attributed to higher ecosystem respiration (RE) and similar gross primary production (GPP) in 2014 because the GPP increased with the MAT, but became saturated due to the limit in photosynthetic capacity. In the spring (March to May) of 2012, low air temperature $\left(T_{\mathrm{a}}\right)$ and drought events delayed grass germination and reduced GPP. In the late wet season (September to October) of 2012 and 2013, the low $T_{\mathrm{a}}$ in September and its negative effects on vegetation growth caused earlier grass senescence and significantly lower GPP. This indicates that the seasonal pattern of $T_{\mathrm{a}}$ has a substantial effect on the annual total GPP, which is consistent with results obtained using the homogeneityof-slopes (HOS) model. The model results showed that the climatic seasonal variation explained $48.6 \%$ of the GPP variability, while the percentages explained by climatic interannual variation and the ecosystem functional change were 9.7 and $10.6 \%$, respectively.
\end{abstract}

\section{Introduction}

In the last decade, the carbon dioxide exchange in grassland ecosystems has attracted much attention (Baldocchi, 2008; Huang et al., 2008; Hunt et al., 2004; Jing et al., 2010; Suyker et al., 2003) because grasslands cover $32 \%$ of the global land surface and make a substantial contribution to the carbon cycle on a global scale (Parton et al., 1995). The annual net ecosystem exchange (NEE) of grasslands has a large range, from -650 to $160 \mathrm{~g} \mathrm{C} \mathrm{m}^{-2} \mathrm{yr}^{-1}$, due to climate variability and land use changes (Gilmanov et al., 2007; Wang et al., 2016a). The climatic factors controlling $\mathrm{CO}_{2}$ exchange also vary under different climate conditions (Du and Liu, 2013; Huang et al., 2016; Xu and Baldocchi, 2004). Most previous studies have focused on low-lying grasslands (Gilmanov et al., 2010).

Alpine meadows in China are the primary grassland type of the nation and are mainly distributed in the QinghaiTibetan plateau (DAHV and CISNR, 1996; Liu et al., 2008). The warming trend in high-altitude areas, such as the Tibetan Plateau and its south-east margin, has been observed to be more pronounced (Fan et al., 2011; Liu and Chen, 2000). Several studies of $\mathrm{CO}_{2}$ exchange have been carried out on the Qinghai-Tibetan plateau, where the mean annual air temperature $\left(T_{\mathrm{a}}\right)$ is approximately $0^{\circ} \mathrm{C}$ (Gu et al., 2003; Kato et al., 2006; Shi et al., 2006; Zhao et al., 2006). The daily $\mathrm{CO}_{2}$ fluxes of the alpine meadow steppe in Damxung, Tibet were shown to be jointly affected by $T_{\mathrm{a}}$ and soil moisture (Fu et al., 2009), while the daily $\mathrm{CO}_{2}$ fluxes of an alpine shrubland at Haibei, Qinghai were found to be sensitive to $T_{\mathrm{a}}$ (Zhao et al., 2006). On an annual scale, the measurements at the Haibei 


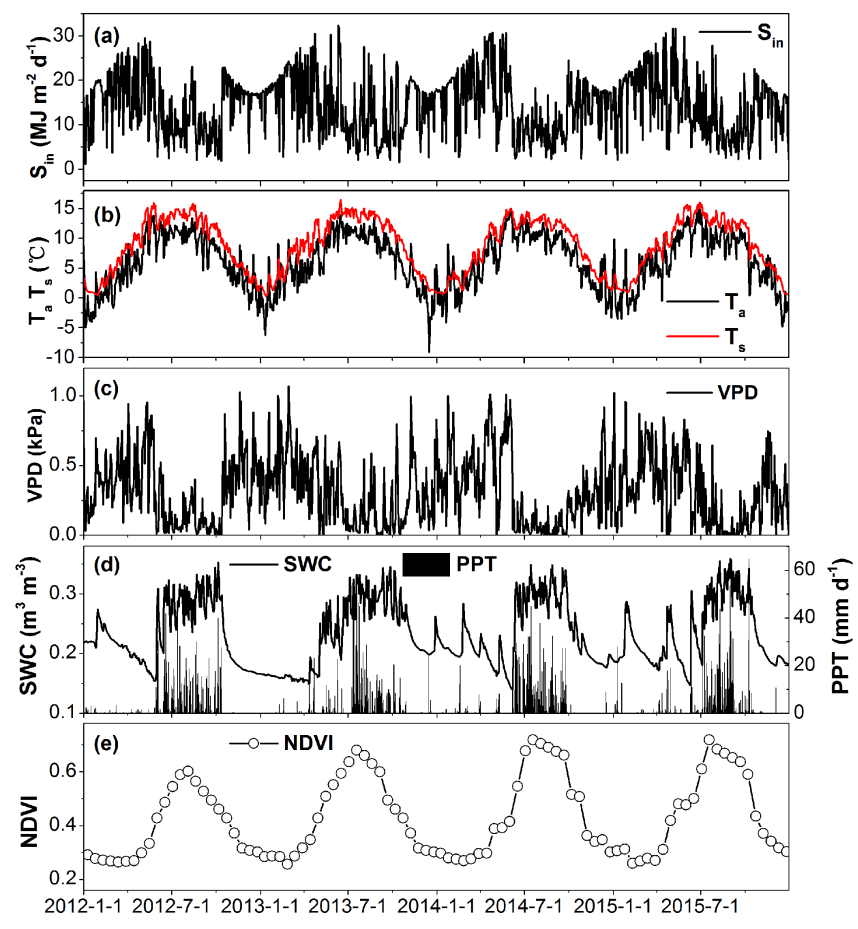

Figure 1. (a) Daily sum of solar radiation $\left(S_{\text {in }}\right)$, (b) daily mean air temperature $\left(T_{\mathrm{a}}\right)$, soil temperature $\left(T_{\mathrm{S}}\right),(\mathbf{c})$ vapour pressure deficit (VPD, $5 \mathrm{~cm}$ ), (d) soil water content ( $\mathrm{SWC}, 5 \mathrm{~cm}$ ), daily total precipitation (PPT) and (e) 16-day average normalized difference vegetation index (NDVI) from 2012 to 2015.

alpine meadow revealed that the annual $\mathrm{CO}_{2}$ uptake was increased by the earlier onset of the growing season, which was caused by higher $T_{\mathrm{a}}$ (Kato et al., 2006). The Lijiang alpine meadow is located in a much warmer area (the mean annual $T_{\mathrm{a}}$ is $12.7^{\circ} \mathrm{C}$ ). A spring drought event and relatively low soil moisture were shown to significantly delay the start time of grass germination and reduce the annual $\mathrm{CO}_{2}$ uptake (Wang et al., 2016b). How the annual $\mathrm{CO}_{2}$ exchange responds to the mean annual $T_{\mathrm{a}}$ is not clear for alpine meadow ecosystems.

Previous studies have attributed year-to-year changes in $\mathrm{CO}_{2}$ exchange to climatic variability (Hui et al., 2003; Xu and Baldocchi, 2004). Fluxes may directly respond to climatic drivers or be indirectly affected by functional changes or changes in the flux-climate relationships (Polley et al., 2008). Statistical models have been used to partition the interannual variation (IAV) of the $\mathrm{CO}_{2}$ exchange (Hui et al., 2003; Richardson et al., 2007; Teklemariam et al., 2010). For example, Shao et al. (2014) found that $77 \%$ of the observed variation in NEE was explained by functional changes in the moist grassland in USA, while variations in climatic variables could better explain the IAV of NEE of a meadow in Denmark (Jensen et al., 2017) and mixed-grass prairies in the semi-arid area of USA (Polley et al., 2008). The relative importance of the direct and indirect effects of the climatic
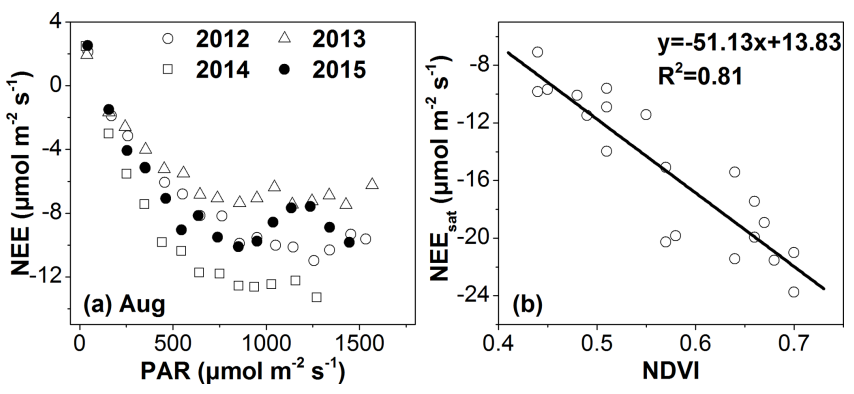

Figure 2. The relationship between daytime NEE and PAR (a) for August from 2012 to 2015 . The NEE and PAR data were averaged with PAR bins of $100 \mu \mathrm{mol} \mathrm{m} \mathrm{m}^{-2} \mathrm{~s}^{-1}$. (b) The relationship between $\mathrm{NEE}_{\text {sat }}$ and NDVI on a monthly scale.

variables on the interannual variations in $\mathrm{CO}_{2}$ exchange for alpine meadows in China has not been quantified.

The $\mathrm{CO}_{2}$ exchange between the atmosphere and the Lijiang alpine meadow was measured using an eddy covariance technique from 2012 to 2015 . The objectives of this study were to (1) examine the seasonal and interannual variation in NEE, gross primary production (GPP), ecosystem respiration (RE) and the parameters of ecosystem photosynthesis and RE; (2) investigate the main environmental controls of the total GPP, RE and NEE on seasonal and annual scales; and (3) partition the interannual variation in GPP, RE and NEE into climatic variability and vegetation growth.

\section{Observation site and methods}

\subsection{Observation site}

The observation site $\left(27^{\circ} 10^{\prime} \mathrm{N}, 100^{\circ} 14^{\prime} \mathrm{E}, 3560 \mathrm{~m}\right.$ a.s.l. $)$ is located at Maoniuping in the Yulong snow mountains, to the north of Lijiang city on the south-east margin of the Tibetan Plateau, China. The study area has a plateau monsoon climate, which is influenced by the south-west and south-east monsoons. There are distinct wet and dry seasons, with a wet season from June to October. The 30-year mean annual total precipitation (1981-2010) at Lijiang city (2400 m a.s.l.) is $980.3 \mathrm{~mm}$, and $85 \%$ of the precipitation is concentrated in the wet season. The 30-year mean annual air temperature (MAT) is $12.6^{\circ} \mathrm{C}$ (data from the Lijiang Meteorology Bureau). The dominant species in this alpine meadow are grass of the genus Kobresia Willd, with a maximum height of $20 \mathrm{~cm}$, and the shrub Berberis Linn, with a maximum height of more than $60 \mathrm{~cm}$. The surface is covered by green vegetation, litter and bare soil. The soil type is a loam, with a dark brown colour, which has a lower reflectance than the grass canopy (Guo et al., 2009). 
Table 1. The average value of daily solar radiation $\left(S_{\text {in }}\right.$, $\left.\mathrm{MJ} \mathrm{m}^{-2} \mathrm{~d}^{-1}\right)$, the mean annual air temperature $\left(T_{\mathrm{a}},{ }^{\circ} \mathrm{C}\right)$, the mean annual vapour pressure deficit (VPD, $\mathrm{kPa}$ ), the mean annual soil water content (SWC, $\mathrm{m}^{3} \mathrm{~m}^{-3}$ ), the total amount of precipitation (PPT, $\mathrm{mm}$ ) for the whole year and the wet season, and the maximum value of NDVI for each year from 2011 to 2015.

\begin{tabular}{lrrrr}
\hline Variables & 2012 & 2013 & 2014 & 2015 \\
\hline$S_{\text {in }}$ & 14.23 & 14.40 & 14.44 & 14.59 \\
$T_{\mathrm{a}}$ & 5.93 & 5.92 & 6.32 & 6.16 \\
VPD & 0.32 & 0.30 & 0.32 & 0.30 \\
SWC & 0.232 & 0.227 & 0.232 & 0.233 \\
PPT (whole year) & 1190.4 & 1066.1 & 1204.8 & 1257.4 \\
PPT (wet season) & 1086.5 & 906.1 & 1092.6 & 1067.1 \\
NDVI $_{\max }$ & 0.60 & 0.68 & 0.72 & 0.72 \\
\hline
\end{tabular}

\subsection{Field measurements and normalized difference vegetation index (NDVI)}

The eddy covariance (EC) system was used to measure 3-D wind speed and the $\mathrm{H}_{2} \mathrm{O}$ and $\mathrm{CO}_{2}$ concentrations at a height of $2.5 \mathrm{~m}$, with a $10 \mathrm{~Hz}$ frequency. The system consisted of a three-dimensional sonic anemometer (CSAT3, Campbell Scientific, Logan, UT, USA) and an open-path $\mathrm{CO}_{2} / \mathrm{H}_{2} \mathrm{O}$ infrared gas analyzer (LI-7500A, LI-COR, Lincoln, NE, USA). The low response measurements $(1 / 3 \mathrm{~Hz}$ frequency) made in this study were $T_{\mathrm{a}}$ and relative humidity at a height of $2.5 \mathrm{~m}$ close to the EC system (HMP45C, Campbell Scientific). Net radiation (including shortwave and longwave radiation, CNR4, Kipp\&Zonen, Delft, Netherlands) and photosynthetically active radiation (PAR; LI190SB, LI-COR) were measured at $1.5 \mathrm{~m}$. Soil temperature (109-L, Campbell Scientific) and soil water content (SWC; CS616, Campbell Scientific) were measured at a depth of $5 \mathrm{~cm}$ below the ground. The precipitation (including solid precipitation in the winter) was measured using a weighing bucket precipitation gauge (T-200B, Geonor, Eiksmarka, Norway). All measurements were controlled by a data logger (CR3000, Campbell Scientific), and the data were stored on a 2-GB CF card.

Four points around the flux tower were selected to investigate the variations in vegetation growth. The $250 \times 250 \mathrm{~m}^{2}$ gridded NDVI data at 16-day intervals (product name: MOD13Q1) for the four points were obtained from the Moderate Resolution Imaging Spectrometer (MODIS) on the EOS-1Terra satellite and were averaged to represent the meadow at this observation site. Observations affected by clouds were removed during this process, and the gaps were filled linearly.

\subsection{Flux calculation and quality control}

EddyPro software (version 5.1, LI-COR) was used to calculate the half-hourly $\mathrm{CO}_{2}$ flux based on the $10 \mathrm{~Hz}$ raw data. After a spike detection (Vickers and Mahrt, 1997), the sector-

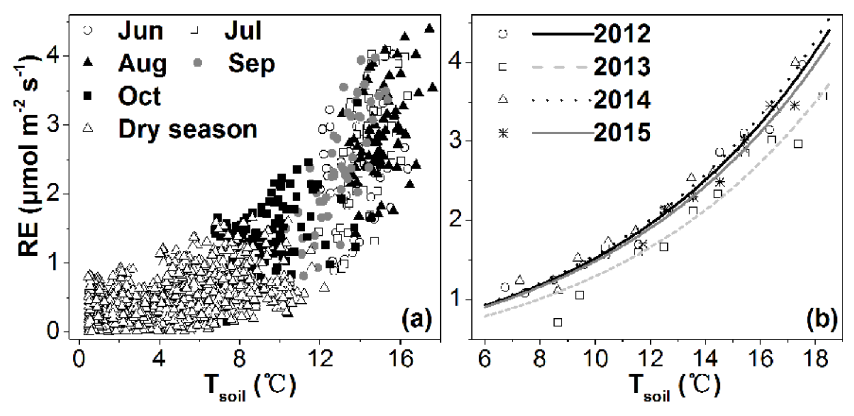

Figure 3. (a) Relationship between RE and $T_{\text {soil }}$ in 2012; (b) relationship between RE and Tsoil for the wet season from 2012 to 2015; RE and $T_{\text {soil }}$ were averaged with $T_{\text {soil }}$ bins of $1^{\circ} \mathrm{C}$.

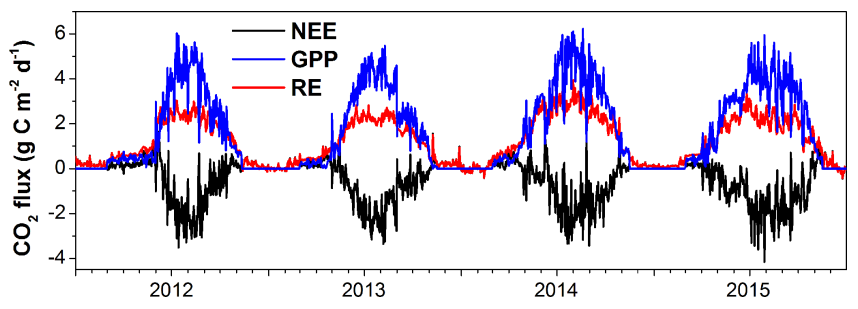

Figure 4. The daily mean NEE, GPP and RE from 2012 to 2015.

wise planar fit method was used to transform the coordinate system due to a terrain slope of approximately $10^{\circ}$ (Wilczak et al., 2001). The $\mathrm{CO}_{2}$ flux was also subjected to a spectral loss correction (Moore, 1986) and density correction (WPL correction; Webb et al., 1980).

Stationary and integral turbulence characteristics tests were used for flux quality control (Foken and Wichura, 1996). When $u^{*}$ was less than $0.1 \mathrm{~m} \mathrm{~s}^{-1}$, the $\mathrm{CO}_{2}$ flux was dependent on $u^{*}$ and was discarded. Because there was a coniferous forest approximately $350 \mathrm{~m}$ to the north of the site, an analytical footprint model was used to determine whether the half-hourly $\mathrm{CO}_{2}$ flux was influenced by the forest and needed to be removed (Kormann and Meixner, 2001).

After quality control, approximately $70 \%$ of the $\mathrm{CO}_{2}$ fluxes were subjected to further analysis. Linear interpolation was used to fill flux gaps of less than $2 \mathrm{~h}$. To fill gaps of longer than $2 \mathrm{~h}$, marginal distribution sampling, an improved look-up table method, was used (Falge et al., 2001; Lloyd and Taylor, 1994).

\subsection{Data analysis}

Using the homogeneity-of-slopes (HOS) model (Hui et al., 2003), the control of the $\mathrm{CO}_{2}$ exchanges (NEE, GPP and RE) was statistically partitioned into four components: the interannual variation of environmental variables $\left(\mathrm{SS}_{\mathrm{i}}\right)$, the seasonal variation of environmental variables $\left(\mathrm{SS}_{\mathrm{s}}\right)$, variations of biological variables ( $\mathrm{SS}_{\mathrm{f}}, \mathrm{NDVI}$ in this study) and random error $\left(\mathrm{SS}_{\mathrm{e}}\right.$, resulting from measurement and analysis random error). To identify the significant control variables, a multi- 
Table 2. The ecosystem photosynthesis parameters using Eq. (1) $\left(\mathrm{NEE}_{\mathrm{sat}}: \mu \mathrm{mol} \mathrm{m} \mathrm{m}^{-2} \mathrm{~s}^{-1}, \alpha: \mu \mathrm{mol} \mathrm{m}^{-2} \mathrm{~s}^{-1}, R^{2}\right)$ and NDVI for each month

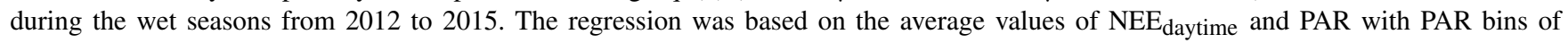
$100 \mu \mathrm{mol} \mathrm{m}{ }^{-2} \mathrm{~s}^{-1} . \mathrm{NEE}_{\mathrm{sat}}^{(\mathrm{a})}$ represents the mean value and the standard deviation, $\mathrm{NEE}_{\mathrm{sat}}^{(\mathrm{b})}$ and $\mathrm{NEE}_{\mathrm{sat}}^{(\mathrm{c})}$ represent the maximum and minimum values of NEEsat for each month.

\begin{tabular}{lrrrrr}
\hline Month & $\mathrm{NEE}_{\text {sat }}^{\mathrm{a}}$ & $\mathrm{NEE}_{\mathrm{sat}}^{\mathrm{b}}$ & $\mathrm{NEE}_{\mathrm{sat}}^{\mathrm{c}}$ & $\alpha$ & $\mathrm{RE}_{\text {bulk }}$ \\
\hline June & $-11.59 \pm 2.45$ & -9.69 & -15.08 & $-0.037 \pm 0.009$ & $3.59 \pm 0.52$ \\
July & $-19.67 \pm 1.54$ & -17.46 & -21 & $-0.050 \pm 0.009$ & $3.75 \pm 0.83$ \\
August & $-20.14 \pm 3.52$ & -15.43 & -23.75 & $-0.055 \pm 0.016$ & $4.15 \pm 0.74$ \\
September & $-16.44 \pm 4.56$ & -11.43 & -21.44 & $-0.051 \pm 0.017$ & $3.70 \pm 1.04$ \\
October & $-9.36 \pm 1.62$ & -7.08 & -10.9 & $-0.031 \pm 0.005$ & $2.45 \pm 0.37$ \\
\hline
\end{tabular}

ple stepwise regression analysis of the $\mathrm{CO}_{2}$ exchanges with environmental variables was conducted using SPSS 12.0 for Windows (SPSS Inc., Chicago, IL, USA). The environmental variables that were significantly correlated with fluxes were submitted for further HOS analysis, while the others were excluded from the analysis. To minimize errors, the daily NEE, GPP and RE were excluded from regressions if more than $50 \%$ of the data points in the daytime $\left(R_{n}>5 \mathrm{~W} \mathrm{~m}^{-2}\right)$ were missing. More details of the HOS model are provided in Hui et al. (2003).

The relationship between daytime $\mathrm{NEE}\left(\mathrm{NEE}_{\text {daytime }}\right)$ and PAR was described by the Michaelis-Menten model (Falge et al., 2001):

$\mathrm{NEE}_{\text {daytime }}=\frac{\alpha \mathrm{NEE}_{\mathrm{sat}} \mathrm{PAR}}{\alpha \mathrm{PAR}+\mathrm{NEE}_{\mathrm{sat}}}+\mathrm{RE}_{\text {bulk }}$,

where $\mathrm{NEE}_{\mathrm{sat}}$ is the NEE at the saturated light level, $\alpha$ is the apparent quantum yield ( $\mu \mathrm{mol} \mathrm{CO} 2 \mu \mathrm{mol}^{-1}$ photons), and $\mathrm{RE}_{\text {bulk }}$ is the bulk estimated RE.

The Van 't Hoff equation was used to evaluate the relationship between the night-time $\mathrm{NEE}$ ( $\mathrm{NEE}_{\text {nighttime, }}$ $\mu \mathrm{mol} \mathrm{CO} \mathrm{m}^{-2} \mathrm{~s}^{-1}$ ) and soil temperature at a depth of $5 \mathrm{~cm}$ $\left(T_{\mathrm{s}},{ }^{\circ} \mathrm{C}\right.$; Aires et al., 2008):

$\mathrm{NEE}_{\text {nighttime }}=a \exp \left(b T_{s}\right)$

where $a$ and $b$ are the regression parameters. The temperature sensitivity coefficient $\left(Q_{10}\right)$ of RE was determined using the following equation.

$Q_{10}=\exp (10 b)$

The partitioning of NEE into GPP and RE was based on the assumption that the sensitivity of RE to soil temperature was the same during the day and at night (Falge et al., 2001). The regression parameters derived from the night-time data were extrapolated to the daytime to calculate the daytime RE and the daily RE. The daily GPP was calculated as follows:

$\mathrm{GPP}=\mathrm{RE}-\mathrm{NEE}$.

\section{Results}

\subsection{Weather conditions and NDVI}

The daily integrated solar radiation $\left(S_{\text {in }}\right)$ varied from 1.15 to 32.40 $\mathrm{MJ} \mathrm{m}^{-2} \mathrm{~d}^{-1}$ (Fig. 1a). The mean $S_{\text {in }}$ in spring (March to May) was 17.0 to $19.93 \mathrm{MJ} \mathrm{m}^{-2} \mathrm{~d}^{-1}$ and was clearly larger than in other seasons. In the wet season, the mean $S_{\text {in }}$ was 9.99 to $11.05 \mathrm{MJ} \mathrm{m}^{-2} \mathrm{~d}^{-1}$.

The MAT was 5.92 to $6.32^{\circ} \mathrm{C}$ (Table 1 ). The daily mean $T_{\mathrm{a}}$ ranged from 0.41 to $14.96^{\circ} \mathrm{C}$ in the wet season and decreased to a minimum value of $-9.06^{\circ} \mathrm{C}$ in the winter. In contrast, the soil temperature never decreased below $0^{\circ} \mathrm{C}$, and the maximum value was $16.48^{\circ} \mathrm{C}$ (Fig. 1b). The vapour pressure deficit (VPD) reached its maximum value of $1.07 \mathrm{kPa}$ before the wet season (Fig. 1c). The VPD decreased to near $0 \mathrm{kPa}$, and the mean VPD for the wet season was 0.125 to $0.166 \mathrm{kPa}$.

The annual precipitation from 2012 to 2015 ranged from 1066.1 to $1257.4 \mathrm{~mm}$. The precipitation during the wet season ranged from 906.1 to $1092.6 \mathrm{~mm}$, accounting for 85 to $91 \%$ of the annual total precipitation (Table 1 ). The mean annual SWC had a small interannual variability, from 0.227 to $0.233 \mathrm{~m}^{3} \mathrm{~m}^{-3}$. In the wet season, the $\mathrm{SWC}$ reached a maximum value of approximately $0.35 \mathrm{~m}^{3} \mathrm{~m}^{-3}$, and the minimum SWC was $0.15 \mathrm{~m}^{3} \mathrm{~m}^{-3}$ (Fig. 1d).

The NDVI of this alpine meadow displayed a clear seasonal and interannual variation (Fig. 1e). The NDVI exceeded 0.4 at the end of April or in late May, depending on the amount and distribution of precipitation in the spring (March to May). The maximum NDVI for each year ranged from 0.60 (2012) to 0.72 (2013). In all 4 years, the NDVI decreased to below 0.4 at the end of October.

\subsection{Seasonal and interannual variations in $\mathrm{NEE}_{\mathrm{sat}}, \alpha$ and $Q_{10}$}

The daytime NEE and PAR were averaged, with PAR bins of $100 \mu \mathrm{mol} \mathrm{m}{ }^{-2} \mathrm{~s}^{-1}$ to avoid random errors. For each month in the wet season, the daytime NEE decreased with PAR until a critical PAR was reached. Above the critical PAR, the daytime NEE increased and the $\mathrm{CO}_{2}$ uptake was de- 
Table 3. The ecosystem respiration parameters using Eqs. (2) and (3) (a: $\mu \mathrm{mol} \mathrm{m} \mathrm{m}^{-2} \mathrm{~s}^{-1}$, b: $Q_{10}, R^{2}$ ) for the wet and dry seasons from 2012 to 2015 . The regression was based on the average values of RE and $T_{\text {soil }}$ with $T_{\text {soil }}$ bins of $1{ }^{\circ} \mathrm{C}$.

\begin{tabular}{lrrrrc}
\hline Season & Year & $\mathrm{a}$ & $\mathrm{b}$ & $Q_{10}$ & $R^{2}$ \\
\hline Wet season & 2012 & 0.437 & 0.125 & 3.48 & 0.98 \\
& 2013 & 0.374 & 0.124 & 3.46 & 0.94 \\
& 2014 & 0.442 & 0.126 & 3.51 & 0.98 \\
& 2015 & 0.433 & 0.123 & 3.43 & 0.98 \\
\hline Dry season & 2012 & 0.338 & 0.081 & 2.25 & 0.78 \\
& 2013 & 0.202 & 0.096 & 2.60 & 0.74 \\
& 2014 & 0.283 & 0.115 & 3.15 & 0.99 \\
& 2015 & 0.313 & 0.104 & 2.82 & 0.70 \\
\hline
\end{tabular}

pressed (Fig. 2a). To derive $\mathrm{NEE}_{\mathrm{sat}}$ and $\alpha$, the NEE and PAR data were used only when PAR was below the critical value. $\mathrm{NEE}_{\text {sat }}$ showed a clear seasonal variation (Table 2). The mean $\mathrm{NEE}_{\text {sat }}$ values for each month showed that $\mathrm{NEE}_{\mathrm{sat}}$ began to increase in June $\left(-11.59 \mu \mathrm{mol} \mathrm{m}^{-2} \mathrm{~s}^{-1}\right)$ and reached a maximum in August $\left(-20.14 \mu \mathrm{mol} \mathrm{m}^{-2} \mathrm{~s}^{-1}\right)$. The highest $\mathrm{NEE}_{\text {sat }}$ during the whole observation period occurred in August of $2014\left(-23.75 \mu \mathrm{mol} \mathrm{m}^{-2} \mathrm{~s}^{-1}\right)$. NEE then declined with grass senescence in September and October. The $\mathrm{NEE}_{\text {sat }}$ in October $\left(-9.36 \mu \mathrm{mol} \mathrm{m}^{-2} \mathrm{~s}^{-1}\right)$ was less than half that in August. The interannual variations in $\mathrm{NEE}_{\text {sat }}$ were also large. For example, $\mathrm{NEE}_{\text {sat }}$ in September 2015 $\left(-21.44 \mu \mathrm{mol} \mathrm{m}{ }^{-2} \mathrm{~s}^{-1}\right)$ was almost twice that in September $2013\left(-11.43 \mu \mathrm{mol} \mathrm{m}^{-2} \mathrm{~s}^{-1}\right.$; Table 2$)$. On a monthly scale, $81 \%$ of the variation in $\mathrm{NEE}_{\mathrm{sat}}$ could be explained by the mean NDVI (Fig. 2b). Over this meadow, NEE $_{\text {sat }}$ did not significantly correlate with SWC because the soil water conditions were always good in the wet season.

At monthly intervals, there were large random errors in the regression between RE and $T_{\text {soil }}$. For example, the $R^{2}$ for each month of the wet season in 2012 ranged from 0.04 to 0.12 . Thus, in 2012, the data in the wet and dry season were combined to fit the regression (Fig. 3a). The $Q_{10}$ in the wet seasons was similar, at approximately 3.45 (Table 3), which was in the normal range of previous studies (1.2 to 3.7; Falge et al., 2001). These values were clearly higher than those for temperate grasslands (1.99 to 3.07; Wang et al., 2016a), Mediterranean grasslands (1.22 to 2.36; Aires et al., 2008) and the Haibei alpine meadow (1.50 to 2.27; Kato et al., 2004). $Q_{10}$ was lower in the dry season than in the wet season.

\subsection{Seasonal and interannual variation in NEE, GPP and RE}

The ecosystem started to absorb $\mathrm{CO}_{2}$ (negative value of NEE) on DOY 165 in 2012, DOY 137 in 2013, DOY 116 in 2014 and DOY 104 in 2015, and then NEE decreased (Fig. 4). The minimum daily NEE for each year occurred
Table 4. The annual total NEE, GPP and RE $\left(\mathrm{g} \mathrm{Cm}^{-2} \mathrm{yr}^{-1}\right)$ for each year from 2012 to 2015 .

\begin{tabular}{lrrrr}
\hline & 2012 & 2013 & 2014 & 2015 \\
\hline NEE & -114.2 & -158.5 & -159.9 & -212.6 \\
GPP & 522.3 & 546.5 & 669.4 & 661.8 \\
RE & 412.1 & 393.6 & 515.2 & 456.7 \\
\hline
\end{tabular}

Table 5. The percentage of the contributions of the seasonal climatic variation $\left(\mathrm{SS}_{\mathrm{S}}\right)$, interannual climatic variability $\left(\mathrm{SS}_{\mathrm{i}}\right)$, the ecosystem functional change $\left(\mathrm{SS}_{\mathrm{f}}\right)$ and random error $\left(\mathrm{SS}_{\mathrm{e}}\right)$ to the interannual variations in NEE, GPP and RE.

\begin{tabular}{lrrrr}
\hline & SSs & SSi & SSf & SSe \\
\hline NEE & $37.7 \%$ & $7.7 \%$ & $10.3 \%$ & $44.3 \%$ \\
GPP & $48.6 \%$ & $9.7 \%$ & $10.7 \%$ & $31.0 \%$ \\
RE & $48.6 \%$ & $15.6 \%$ & $21.2 \%$ & $14.6 \%$ \\
\hline
\end{tabular}

in July or August (-3.52 on DOY 196 in 2012, -3.35 on DOY 218 in $2013,-3.43$ on DOY 243 in 2014 and $-4.16 \mathrm{~g} \mathrm{C} \mathrm{m}^{-2} \mathrm{~d}^{-1}$ on DOY 210 in 2015). NEE increased significantly in September and became positive on DOY 293 in 2012, DOY 305 in 2013, DOY 295 in 2014 and DOY 297 in 2015. The maximum difference in the start time of $\mathrm{CO}_{2}$ uptake was 61 days while the difference in the end time was 12 days. The $\mathrm{CO}_{2}$ uptake period was much shorter in 2012 (129 days) than in 2013 (169 days), 2014 (180 days) and 2015 (194 days).

The daily GPP increase started earlier than $\mathrm{CO}_{2}$ uptake. The seasonal pattern of daily GPP was similar to that of NEE, although the amplitude of GPP variations was larger than that of NEE variations. The maximum daily GPP for each year was $6.02,5.47,6.23$ and $5.95 \mathrm{~g} \mathrm{C} \mathrm{m}^{-2} \mathrm{~d}^{-1}$ for the 4 years from 2012 to 2015. Compared with the NEE and GPP, the seasonal variation in RE was smaller during the wet season. In particular, RE varied only slightly from June to August.

The annual GPP in 2014 and 2015 was clearly higher than in 2012 and 2013, as indicated by the larger NDVI (Fig. 5; Tables 1, 4). In contrast, the RE in 2014 was the highest of all 4 years because, although the $Q_{10}$ value was similar to the other years, it had the highest $T_{\mathrm{a}}$ (Table 1). Therefore, the annual NEE in 2014 was similar to that in 2013, but lower than that in 2015, although the GPP was similar in 2014 and 2015. The spring drought resulted in a significantly lower NDVI in 2012 than in the other years; consequently, the annual GPP in 2012 was the lowest of all 4 years. The annual NEE for the 4 years followed the order of $2015<2014<2013<2012$ (Table 4), which is consistent with the length of the $\mathrm{CO}_{2}$ uptake period. 

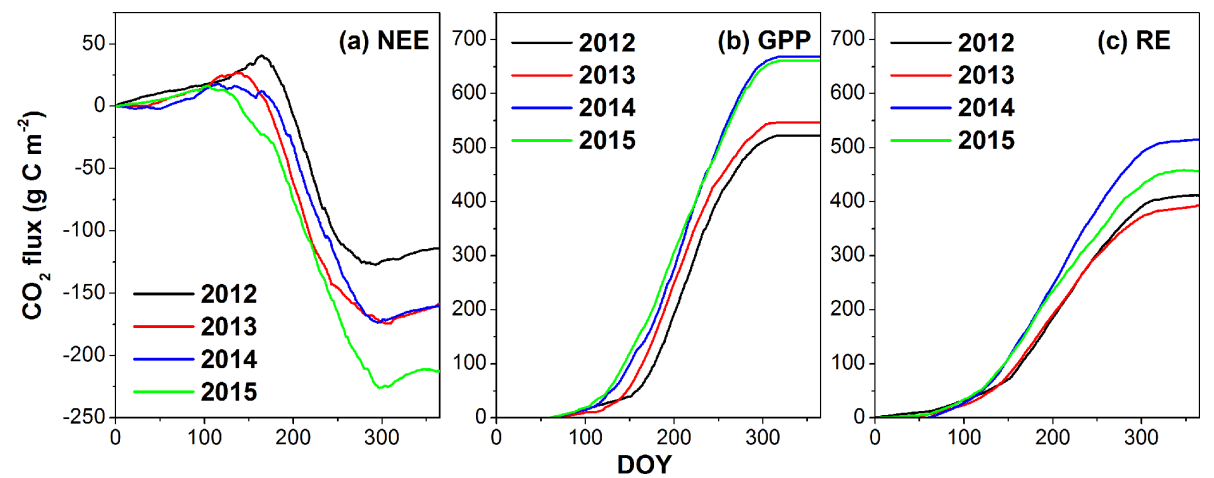

Figure 5. The cumulative NEE, GPP and RE from 2012 to 2015.
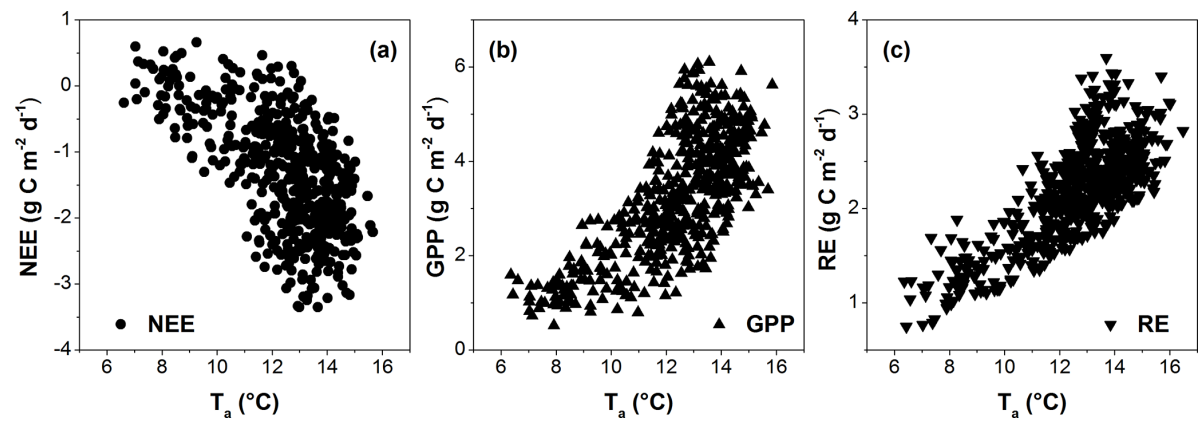

Figure 6. Relationships between (a) NEE and $T_{\mathrm{a}}$, (b) GPP and $T_{\mathrm{a}}$ and (c) RE and $T_{\mathrm{a}}$ for the wet seasons from 2012 to 2015.

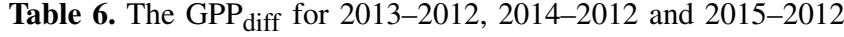
during the periods from March to May, June, from June to July and from August to September.

\begin{tabular}{lrrr}
\hline & \multicolumn{3}{c}{$\mathrm{GPP}_{\text {diff }}$} \\
\cline { 2 - 4 } Periods & $2013-2012$ & $2014-2012$ & $2015-2012$ \\
\hline March to May & 28.0 & $63.1(43 \%)$ & $83.3(60 \%)$ \\
June & $13.4(9 \%)$ & $23.7(17 \%)$ \\
July to August & -8.7 & $14.2(10 \%)$ & $-18.5(-13 \%)$ \\
September to October & -12.0 & $55.2(38 \%)$ & $48.2(35 \%)$ \\
Entire year & 24.2 & 147.1 & 139.5 \\
\hline
\end{tabular}

\section{Discussion}

\subsection{Partitioning the interannual variation in $\mathrm{CO}_{2}$ exchange}

The HOS model was used to partition the interannual variation (IAV) in $\mathrm{CO}_{2}$ exchange into climatic variability and ecosystem functional change, which was reflected by the variability of the flux-climate relationship throughout the years (Hui et al., 2003). During the wet season, the daily NEE, GPP and RE were mainly related to $T_{\mathrm{a}}$ (Fig. 6). The effect of PAR on NEE and GPP was very weak, with $R$ values of -0.05 and 0.08 , respectively.

A separate-slopes model was constructed for each year, and the multiple regression model was based on data from

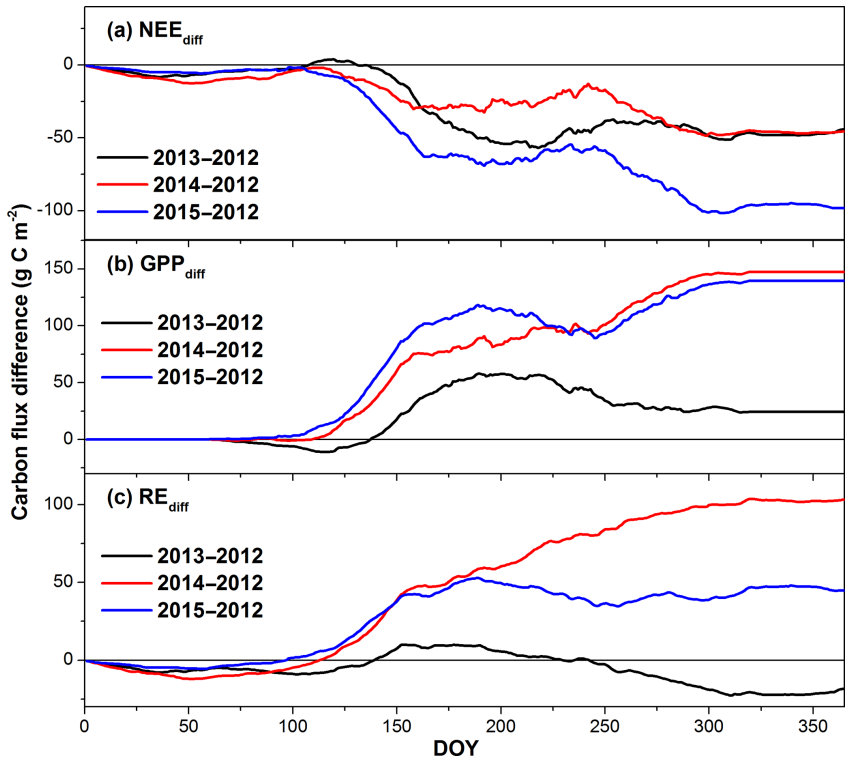

Figure 7. Seasonal variations in the differences of (a) NEE, (b) GPP and (c) RE from 2013 to 2012, from 2014 to 2012 and from 2015 to 2012 .

the observational period. Compared with the multiple regression model, the separate-slopes model substantially improved the NEE estimation, with $R^{2}$ increasing from 0.69 in 


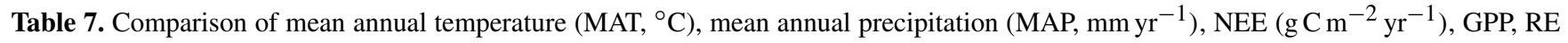
and RE / GPP between this study and previous grassland studies.

\begin{tabular}{|c|c|c|c|c|c|c|c|c|c|c|}
\hline $\begin{array}{l}\text { References/ } \\
\text { Location }\end{array}$ & $\begin{array}{l}\text { Ecosystem } \\
\text { Description }\end{array}$ & Latitude & Longitude & Altitude & MAT & MAP & NEE & GPP & RE & RE / GPP \\
\hline $\begin{array}{l}\text { This study/ } \\
\text { Lijiang, China }\end{array}$ & $\begin{array}{l}\text { Alpine meadow/ } \\
\text { shrub }\end{array}$ & $27^{\circ} 10^{\prime} \mathrm{N}$ & $100^{\circ} 14^{\prime} \mathrm{E}$ & 3560 & 6.1 & 1180 & $\begin{array}{r}-161(-213 \\
\text { to }-114)\end{array}$ & $\begin{array}{r}600(522 \\
\text { to } 669)\end{array}$ & $\begin{array}{r}444(394 \\
\text { to } 515)\end{array}$ & $\begin{array}{r}0.74(0.69 \\
\text { to } 0.79)\end{array}$ \\
\hline $\begin{array}{l}\text { Yu et al. (2006)/ } \\
\text { Damxung, China }\end{array}$ & Alpine meadow & $30^{\circ} 51^{\prime} \mathrm{N}$ & $90^{\circ} 05^{\prime} \mathrm{E}$ & 4250 & 2.1 & 520 & $\begin{array}{r}28(16 \\
\text { and } 39)\end{array}$ & $\begin{array}{l}167(144 \\
\text { and } 190)\end{array}$ & $\begin{array}{l}195(183 \\
\text { and 206) }\end{array}$ & $\begin{array}{r}1.16(1.08 \\
\text { and } 1.27)\end{array}$ \\
\hline $\begin{array}{l}\text { Kato et al. }(2006) / \\
\text { Haibei, China }\end{array}$ & $\begin{array}{l}\text { Alpine } \\
\text { shrub }\end{array}$ & $37^{\circ} 37^{\prime} \mathrm{N}$ & $101^{\circ} 18^{\prime} \mathrm{E}$ & 3250 & -1.0 & 566 & $\begin{array}{r}-121(-193 \\
\text { to }-79)\end{array}$ & $\begin{array}{r}634(575 \\
\text { to } 681)\end{array}$ & $\begin{array}{r}514(489 \\
\text { to } 556)\end{array}$ & $\begin{array}{r}0.81(0.72 \\
\text { to } 0.86)\end{array}$ \\
\hline $\begin{array}{l}\text { Shimoda et al. (2005)/ } \\
\text { Japan }\end{array}$ & C3/C4 grassland & $36^{\circ} 06^{\prime} \mathrm{N}$ & $140^{\circ} 06^{\prime} \mathrm{E}$ & 27 & 13.9 & 1156 & $\begin{array}{r}-17(-78 \\
\text { to } 17)\end{array}$ & $\begin{array}{r}2365(2285 \\
\text { to } 2426)\end{array}$ & $\begin{array}{r}2348(2303 \\
\text { to } 2392)\end{array}$ & $\begin{array}{r}0.99(0.97 \\
\text { to } 1.01)\end{array}$ \\
\hline $\begin{array}{l}\text { Aires et al. (2008)/ } \\
\text { Portugal }\end{array}$ & $\begin{array}{l}\text { Mediterranean } \\
\text { grassland }\end{array}$ & $38^{\circ} 28^{\prime} \mathrm{N}$ & $8^{\circ} 01^{\prime} \mathrm{E}$ & 140 & 15.5 & 669 & $\begin{array}{r}-71(-190 \\
\text { and } 49)\end{array}$ & $\begin{array}{r}893(524 \\
\text { and } 1261)\end{array}$ & $\begin{array}{r}822(573 \\
\text { and } 1071)\end{array}$ & $\begin{array}{r}0.92(0.85 \\
\text { and } 1.09)\end{array}$ \\
\hline $\begin{array}{l}\text { Jensen et al. (2017)/ } \\
\text { Denmark }\end{array}$ & Meadow & $55^{\circ} 55^{\prime} \mathrm{N}$ & $8^{\circ} 24^{\prime} \mathrm{E}$ & 0 & 8.7 & 809 & $\begin{array}{r}-156(-356 \\
\text { to }-18)\end{array}$ & $\begin{array}{r}1349(1147 \\
\text { to } 1570)\end{array}$ & $\begin{array}{r}1193(1069 \\
\text { to } 1406)\end{array}$ & $\begin{array}{r}0.88(0.75 \\
\text { to } 0.98)\end{array}$ \\
\hline $\begin{array}{l}\text { Gilmanov et al. (2007)/ } \\
\text { Europe }\end{array}$ & $\begin{array}{l}\text { Multiple } \\
\text { (19 sites) }\end{array}$ & - & - & $\begin{array}{r}-0.7 \\
\text { to } 1770\end{array}$ & $\begin{array}{r}3.9 \\
\text { to } 14.6\end{array}$ & $\begin{array}{r}387 \\
\text { to } 1816\end{array}$ & $\begin{array}{r}-150(-653 \\
\text { to } 171)\end{array}$ & $\begin{array}{r}1261(467 \\
\text { to } 1874)\end{array}$ & $\begin{array}{r}1111(493 \\
\text { to } 1622)\end{array}$ & $\begin{array}{r}0.90(0.59 \\
\text { to } 1.14)\end{array}$ \\
\hline $\begin{array}{l}\text { Xu and Baldocchi (2004)/ } \\
\text { USA }\end{array}$ & $\begin{array}{l}\text { Mediterranean } \\
\text { grassland }\end{array}$ & $38^{\circ} 24^{\prime} \mathrm{N}$ & $120^{\circ} 57^{\prime} \mathrm{E}$ & 129 & 16.3 & 559 & $\begin{array}{r}-52(-132 \\
\text { and } 29)\end{array}$ & $\begin{array}{l}798(729 \\
\text { and } 867)\end{array}$ & $\begin{array}{l}747(735 \\
\text { and } 758)\end{array}$ & $\begin{array}{r}0.94(0.85 \\
\text { and } 1.04)\end{array}$ \\
\hline $\begin{array}{l}\text { Flanagan et al. (2002)/ } \\
\text { Canada }\end{array}$ & $\begin{array}{l}\text { Temperate } \\
\text { grassland }\end{array}$ & $49^{\circ} 26^{\prime} \mathrm{N}$ & $112^{\circ} 34^{\prime} \mathrm{E}$ & 951 & - & 378 & $\begin{array}{r}-2(-21 \\
\text { and } 18)\end{array}$ & $\begin{array}{l}280(272 \\
\text { and } 287)\end{array}$ & $\begin{array}{l}278(267 \\
\text { and } 290)\end{array}$ & $\begin{array}{r}1.0(0.93 \\
\text { and } 1.07)\end{array}$ \\
\hline
\end{tabular}
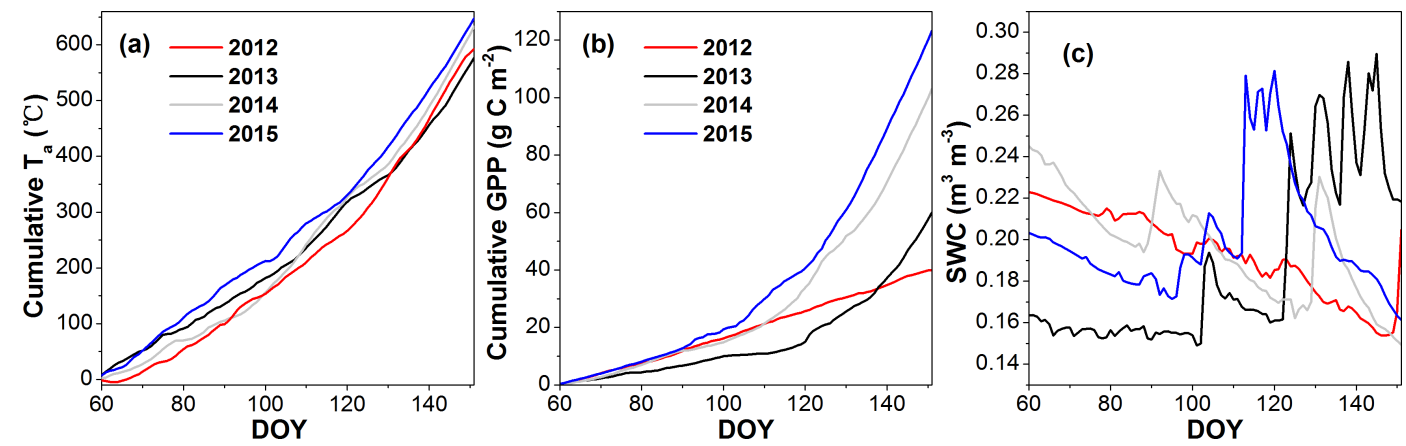

Figure 8. Cumulative (a) $T_{\mathrm{a}}$ and (b) GPP and (c) the daily mean SWC from March to May (DOY60 to 151) for 2012, 2013,2014 and 2015.

the multiple regression model to 0.79 in the separate-slopes model. This means that the separate-slopes model accounted for $10.3 \%$ more variation in the observed NEE than the multiple regression model, which was attributed to the functional change $\left(\mathrm{SS}_{\mathrm{f}}\right)$. The other $89.7 \%$ of the variation in the observed NEE was partitioned to interannual climatic variability $\left(\mathrm{SS}_{\mathrm{i}}, 7.7 \%\right)$, seasonal climatic variation $\left(\mathrm{SS}_{\mathrm{s}}, 37.7 \%\right)$ and random error $\left(\mathrm{SS}_{\mathrm{e}}, 44.3 \%\right.$; Table 5). Therefore, most of the IAV in NEE, GPP and RE was attributable to the variation in climatic variables, in particular, climatic seasonal variation. This is in line with the findings reported for a Skjern meadow in Denmark and a temperate ombrotrophic bog in Canada (Jensen et al., 2017; Teklemariam et al., 2010). In contrast, Braswell et al. (1997) and Shao et al. (2014) found that functional change, rather than the direct effects of IAV in climate, accounted for more IAV in fluxes. Moreover, the contributions of different drivers to the IAV in GPP were similar to that of NEE, while the functional change in RE was twice that of NEE and GPP. The $R^{2}$ values for NEE, GPP and $\mathrm{RE}$ in the multiple regression model were $0.44,0.53$ and
0.59. It was considered reasonable that the largest random error was recorded for NEE.

\subsection{Control of the interannual variation in the $\mathrm{CO}_{2}$ exchange}

To examine the interannual variation in $\mathrm{CO}_{2}$ exchange, the cumulative NEE, GPP and RE in 2013, 2014 and 2015 were compared with the corresponding values in 2012 (Fig. 7). The cumulative $\mathrm{NEE}_{\text {diff }}$ (the difference in NEE) values for 2014-2012 and 2015-2012 increased rapidly in spring and autumn. In summer, the differences between 2012, 2014 and 2015 varied slightly. The cumulative $\mathrm{NEE}_{\text {diff }}$ for 2013 2012 increased from April to early August. These patterns were similar to those for $\mathrm{GPP}_{\text {diff. However, the annual }}$ cumulative $\mathrm{GPP}_{\text {diff }}\left(24.3\right.$ to $147.2 \mathrm{~g} \mathrm{C} \mathrm{m}^{-2} \mathrm{yr}^{-1}$ ) was relatively larger than the annual cumulative $\mathrm{NEE}_{\text {diff }}(-44.2$ to $-98.3 \mathrm{~g} \mathrm{C} \mathrm{m}^{-2} \mathrm{yr}^{-1}$ ). The cumulative $\mathrm{RE}_{\text {diff }}$ decreased from DOY 1 and then increased in spring. The cumulative $R_{\text {diff }}$ for 2013-2012 and 2015-2012 reached its maximum at the end of June, while the cumulative $\mathrm{RE}_{\text {diff }}$ for 2014-2012 in- 

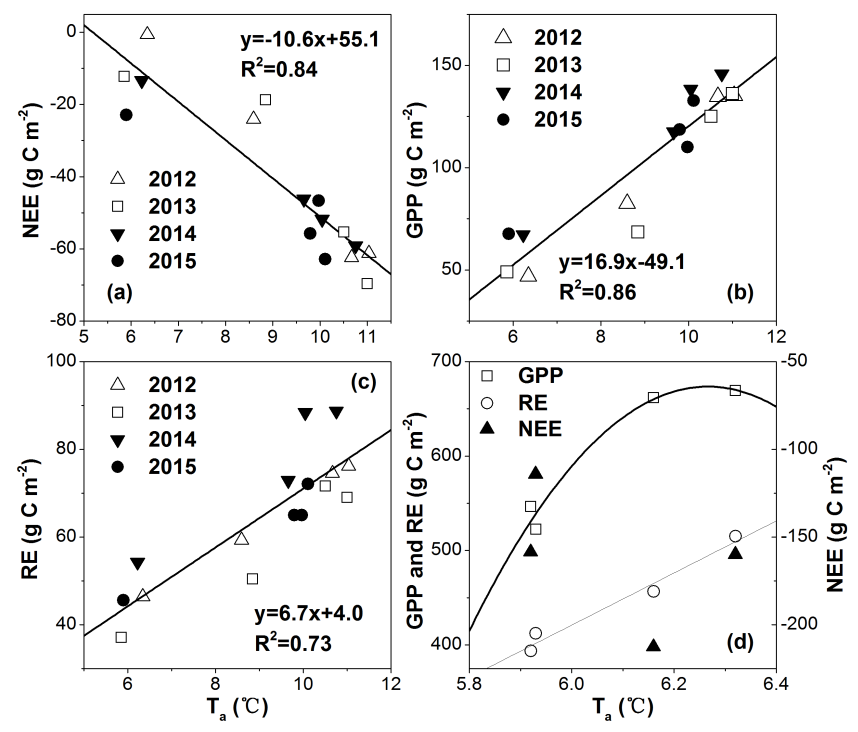

Figure 9. Relationships between (a) NEE and $T_{\mathrm{a}}$; (b) GPP and $T_{\mathrm{a}}$; (c) RE and $T_{\mathrm{S}}$ from July to October at a monthly scale and (d) relationship between the annual total $\mathrm{CO}_{2}$ exchange fluxes and the mean annual $T_{\mathrm{a}}$, which were GPP $=-1191 T_{\mathrm{a}}^{2}+14930 T_{\mathrm{a}}-46102$, $R^{2}=0.97$ and $\mathrm{RE}=276 T_{\mathrm{a}}-1235, R^{2}=0.97$.

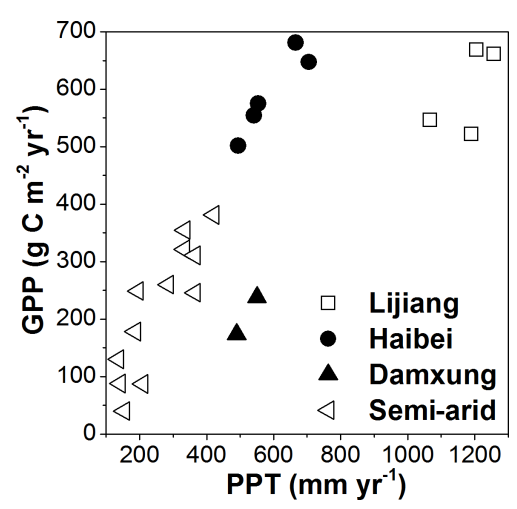

Figure 10. Relationships between the annual GPP and precipitation (PPT) for this Lijiang site, the Haibei site (Kato et al., 2006; Fu et al., 2009), the Damxung site (Fu et al., 2009) and the semi-arid grassland sites (Fu et al., 2009; Du and Liu, 2013; Yang and Zhou, 2013).

creased throughout the entire year and was the largest of all the periods considered.

The daily $\mathrm{CO}_{2}$ uptake over this meadow ecosystem has previously been shown to increase with $T_{\mathrm{a}}$ (Wang et al., 2016). Especially in the spring (March to May), the temperature affected the vegetation growth and GPP. From March to May, the cumulative $T_{\mathrm{a}}$ was $592.3,577.1,633.1$ and $647.6^{\circ} \mathrm{C}$ in the 4 years from 2012 to 2015 . Consequently, the cumulative GPP in the spring increased in the order of $2015>2014>2013$. The exception was that the spring of 2012 had a higher $T_{\mathrm{a}}$, but a lower GPP than the spring of 2013. Compared with the GPP in 2013, the GPP in 2012 in- creased more significantly due to the higher $T_{\mathrm{a}}$ from March to April. However, the drought in May 2012 delayed vegetation growth and reduced GPP. The differences in $\mathrm{GPP}_{\text {cum }}$ for 2013-2012, 2014-2012 and 2015-2012 at the end of May were $20.0,63.1$ and $83.3 \mathrm{~g} \mathrm{C} \mathrm{m}^{-2}$, representing 82.6, 42.9 and $59.7 \%$ of the differences for the three periods.

From July to October, the NEE, GPP and RE were all strongly correlated with $T_{\mathrm{a}}$ on a monthly scale $\left(R^{2}=0.84\right.$, 0.86 and 0.73 ; Fig. $9 \mathrm{a}, \mathrm{b}, \mathrm{c})$. The slope of the relationship between GPP and $T_{\mathrm{a}}$ was much larger than for that between $\mathrm{RE}$ and $T_{\mathrm{a}}$, indicating that when $T_{\mathrm{a}}$ increased, the alpine meadow ecosystem absorbed more $\mathrm{CO}_{2}$. The monthly GPP in July and August varied slightly between the 4 years, while the interannual variability of the GPP in September was the largest because the monthly means $T_{\mathrm{a}}$ in September for 2012 $\left(8.6^{\circ} \mathrm{C}\right)$ and $2013\left(8.8^{\circ} \mathrm{C}\right)$ were significantly lower than those for $2014\left(9.7^{\circ} \mathrm{C}\right)$ and $2015\left(10.0^{\circ} \mathrm{C}\right)$. Consequently, the differences in $\mathrm{GPP}_{\text {cum }}$ for 2014-2012 and 2015-2012 from September to October were 55.2 and $48.2 \mathrm{~g} \mathrm{C} \mathrm{m}^{-2}$, representing 37.5 and $34.6 \%$ of the differences for the two periods.

On the annual scale, the annual total NEE decreased with the MAT in 2012, 2013 and 2015 and then increased when the MAT was highest in 2014. The reason for this was that the annual total RE increased linearly with the MAT $\left(R^{2}=0.97\right)$, while the relationship between the GPP and MAT was non-linear (Fig. 9d). The GPP became saturated as the MAT increased. In contrast, the annual NEE increased with the MAT in the Haibei alpine meadow, which is in line with previous studies showing that the annual NEE is comprehensively controlled by the temperature environment (Kato et al., 2006).

\subsection{Comparison of annual $\mathrm{CO}_{2}$ exchange with other sites}

The annual GPP at the study site was much larger than that reported in semi-arid grasslands in Tibet and Canada (Flanagan et al., 2002; Yu et al., 2006), but much lower than that reported in moist grasslands in low-lying areas in Europe (Table 7). In China, the annual GPP for semi-arid grasslands and the Haibei alpine meadow increased slightly with annual precipitation $\left(R^{2}=0.94\right.$; Fig. 10$)$. With similar annual precipitation, the annual GPP of the Damxung site was much lower than the Haibei site, possibly because of higher elevation. When the annual precipitation increased further, to over $1000 \mathrm{~mm} \mathrm{yr}^{-1}$, the annual GPP remained steady (Fig. 10). The annual GPP for the grassland ecosystems in China was always below $700 \mathrm{~g} \mathrm{C} \mathrm{m}^{-2} \mathrm{yr}^{-1}$.

In addition to temperature effects, the daily $\mathrm{RE}$ was also correlated with the daily GPP $(\mathrm{RE}=0.44 \mathrm{GPP}+0.63$, $R^{2}=0.82$ ) during the wet season from 2012 to 2015 . Due to the high elevation and low soil temperature in the summer, the percentage of RE to GPP for this meadow site was lower than for Mediterranean grass- 
lands $\left(\mathrm{RE}=0.53 \mathrm{GPP}+0.72, R^{2}=0.85\right.$, Aires et al., 2008; $\mathrm{RE}=0.47 \mathrm{GPP}+1.33, R^{2}=0.85, \mathrm{Xu}$ and Baldocchi, 2004). The low level of RE resulted in a similar or even lower annual NEE (mean value: $-161 \mathrm{~g} \mathrm{C} \mathrm{m}^{-2} \mathrm{yr}^{-1}$ ) at Lijiang than in moist grasslands with a low elevation (Table 7). For example, the mean annual NEE for a meadow in Denmark (annual precipitation: $809 \mathrm{~mm}$ ) was $-156 \mathrm{~g} \mathrm{C} \mathrm{m}^{-2} \mathrm{yr}^{-1}$, while the mean annual NEE for a C3/C4 grassland in Japan (annual precipitation: $1156 \mathrm{~mm}$ ) was $-17 \mathrm{~g} \mathrm{C} \mathrm{m}^{-2} \mathrm{yr}^{-1}$. The ratio of $\mathrm{RE}$ to GPP ranged from 0.69 to 0.79 over the Lijiang alpine meadow, which was lower than the Haibei alpine meadow (Table 7). This is why the annual NEE at the Lijiang site was on average $25 \%$ lower than at the Haibei site. In general, low RE / GPP ratios occurred in high-altitude and moist areas. The alpine meadow ecosystem (Lijiang and Haibei) had a lower RE / GPP ratio than most low-lying grasslands. Compared with semi-arid grasslands (RE / GPP: approximately 1.0), the RE / GPP ratios reported in moist grasslands are much lower, e.g. a sown grassland in the Netherlands $(0.60)$ and a natural grassland in Italy (0.59; Gilmanov et al., 2007).

\section{Conclusions}

The 4-year EC data from 2012 to 2015 were used to investigate the interannual variation in the NEE, GPP and RE. The key parameters for ecosystem photosynthesis and respiration were determined for the different seasons of each year. The vegetation growth (NDVI) controlled $\mathrm{NEE}_{\mathrm{sat}}$ on a monthly scale, and the interannual variation in $Q_{10}$ for the wet and dry seasons was small. The seasonal variation in $\mathrm{CO}_{2}$ exchange was affected by the seasonal pattern of $T_{\mathrm{a}}$ and the soil moisture in the spring. In the spring, low $T_{\mathrm{a}}$ and drought events delayed the start time of $\mathrm{CO}_{2}$ uptake. In the late wet season, the higher $T_{\mathrm{a}}$ in 2014 and 2015 resulted in later grass senescence and $\mathrm{CO}_{2}$ release. The annual NEE decreased with the length of the $\mathrm{CO}_{2}$ uptake period, but its relationship with the NDVI was not significant. For this alpine meadow, the HOS model suggests that most of the IAV in NEE, GPP and RE was attributed to the seasonal variation in climatic variables. On an annual scale, the annual RE increased linearly with the MAT, while the annual GPP became saturated when the MAT increased from 6.16 to $6.32^{\circ} \mathrm{C}$. Thus, the annual NEE decreased and then increased with the MAT. The low RE / GPP ratio at the study site was responsible for the lower annual NEE compared with some other grassland ecosystems with a larger GPP.

Data availability. Please contact the corresponding author to access data.

Competing interests. The authors declare that they have no conflict of interest.
Acknowledgements. This study was supported by the National Natural Science Foundation of China (grant no.: 91537212, 41675013, 41661144018, 41461144001, 41305012) and the Third Tibetan Plateau Scientific Experiment: Observations for Boundary Layer and Troposphere (GYHY201406001). The staffs from Lijiang Meteorological Administration are appreciated for their help in the maintenance of the measurements.

Edited by: J. Huang

Reviewed by: two anonymous referees

\section{References}

Aires, L. M., Pio, C. A., and Pereira, J. S.: Carbon dioxide exchange above a Mediterranean $\mathrm{C} 3 / \mathrm{C} 4$ grassland during two climatologically contrasting years, Glob. Change Biol., 14, 539-555, 2008.

Baldocchi, D.: "Breathing" of the terrestrial biosphere:lessons learned from aglobal network of carbon dioxide flux measurement systems, Aust. J. Bot., 56, 1-26, 2008.

Braswell, B. H., Schimel, D. S., Linder, E., and Moore, B.: The response of global terrestrial ecosystems to inter-annual temperature variability, Science, 278, 870-872, 1997.

DAHV (Department of Animal Husbandry and Veterinary, Institute of Grasslands, Chinese Academy of Agricultural Sciences), and CISNR (Commission for Integrated Survey of Natural Resources, Chinese Academy of Sciences): Rangeland resources of China, China Agricultural Science and Technology, Beijing, 1996.

Du, Q. and Liu, H. Z.: Seven years of carbon dioxide exchange over a degraded grasslandand a cropland with maize ecosystems in a semiarid area of China, Agr. Ecosyst. Environ., 173, 1-12, 2013.

Falge, E., Baldocchi, D., and Olson, R.: Gap filling strategies for defensible annual sums of net ecosystem exchange, Agr. Forest Meteorol., 107, 43-69, 2001.

Fan, Z. X., Bräuning, A., Thomas, A., Li, J. B., and Cao, K. F.: Spatial and temporal temperature trends on the Yunnan Plateau (Southwest China) during 1961-2004, Int. J. Climatol., 31, 2078-2090, 2011.

Flanagan, L., Wever, L. A., and Carlson, P: Seasonal and interannual variation in carbon dioxide exchange and carbon balance in a northern temperate grassland, Glob. Change Biol., 8, 599-615, 2002.

Foken, T. and Wichura, B.: Tools for quality assessment of surfacebased flux measurements, Agr. Forest Meteorol., 78, 83-105, 1996.

Fu, Y., Zheng, Z., Yu, G., Hu, Z., Sun, X., Shi, P., Wang, Y., and Zhao, X.: Environmental influences on carbon dioxide fluxes over three grassland ecosystems in China, Biogeosciences, 6, 2879-2893, doi:10.5194/bg-6-2879-2009, 2009.

Gilmanov, T. G., Soussana, G. F., Aires, L., Allard, V., Ammann, C., Balzarolo, M., Barcza, Z., Bernhofer, C., Campbell, C. L., and Cernusca, A.: Partitioning European grassland net ecosystem $\mathrm{CO}_{2}$ exchange into gross primary productivity and ecosystem respiration using light response function analysis, Agr. Ecosyst. Environ., 121, 93-120, 2007.

Gilmanov, T. G., Aires, L., Barcza, Z., Baron, V. S., Belelli, L., Beringer, J., Billesbach, D., Bonal, D., Bradford, J., Ceschia, E., Cook, D., Corradi, C., Frank, A., Gianelle, D., Gimeno, C., 
Grünwald, T., Guo, H., Hanan, N., Haszpra, L., Heilman, J., Jacobs, A., Jones, M. B., Johnson, D. A., Kiely, G., Li, S., Magliulo, V., Moors, E., Nagy, Z., Nasyrov, M., Owensby, C., Pinter, K., Pio, C., Reichstein, M., Sanz, M. J., Scott, R., Soussana, J. F., Stoy, P. C., Svejcar, T., Tuba, Z., and Zhou, G.: Productivity,respiration, and light-response parameters of world grassland andagroecosystems derived from flux-tower measurements, Rangel. Ecol. Manage., 63, 16-39, 2010.

Gu, S., Tang, Y. H., Du, M. Y., Kato, T., Li, Y. N., Cui, X. Y., and Zhao, X. Q.: Short term variation of NEE in relation to environmental controls in an alpine meadow on the Qinghai-Tibetan Plateau, J. Geophys. Res., 108, doi:10.1029/2003JD003584, 2003.

Guo, L. N., He, Z. J., Long, X., Wang, J. Z., Wang, L. D., and Li, C. X.: Soil characteristics and its classification system in Mt. Yulong, China, Guangxi, Agr. Sci., 40, 1177-1183, 2009 (in Chinese).

Huang, J., Zhang, W., Zuo, J., Bi, J., Shi, J., Wang, X., Chang, Z., Huang, Z., Yang, S., Zhang, B., Wang, G., Feng, G., Yuan, J., Zhang, L, Zuo, H., Wang, S., Fu, C., and Chou, J.: An overview of the semi-arid climate and environment research observatory over the Loess Plateau, Adv. Atmos. Sci., 25, 906-921, 2008.

Huang, J., Yu, H., Guan, X., Wang, G., and Guo, R.: Accelerated dryland expansion under climate change, Nat. Clim. Change, 6, 166-171, 2016.

Hui, D., Luo, Y., and Katul, G.: Parititioning interannual variability in net ecosystem exchange between climatic variability and functional change, Tree Physiol., 23, 433-442, 2003.

Hunt, J. E., Kelliher, F. M., Mcseveny, T. M., Ross, D. J., and Whitehead, D.: Long-term carbon exchange in a sparse, seasonally dry tussock grassland, Glob. Change Biol., 10, 1785-1800, 2004.

Jensen, R., Herbst, M., and Friborg, T.: Direct and indirect controls of the interannual variability inatmospheric $\mathrm{CO}_{2}$ exchange of three contrasting ecosystems in Denmark, Agr. Forest Meteorol., 233, 12-31, 2017.

Jing, X., Huang, J., Wang, G., Higuchi, K., Bi, J., Sun, Y., Yu, H., and Wang, T.: The effects of clouds and aerosols on net ecosystem $\mathrm{CO}_{2}$ exchange over semi-arid Loess Plateau of Northwest China, Atmos. Chem. Phys., 10, 8205-8218, doi:10.5194/acp10-8205-2010, 2010.

Kato, T., Tang, Y. H., Gu, S., Cui, X. Y., Hirota, M., Du, M. Y., Li, Y. N., Zhao, X. Q., and Oikawa, T.: Seasonal patterns of gross primary production and ecosystem respiration in an alpine meadow ecosystem on the Qinghai-Tibetan Plateau, J. Geophys. Res., 109, 1045-1056, doi:10.1029/2003JD003951, 2004.

Kato, T., Tang, Y. H., Gu, S., Hirota, M., Du, M. Y., Li, Y. N., and Zhao, X. Q.: Temperature and biomass influences on interannual changes in $\mathrm{CO}_{2}$ exchange in an alpine meadow on the QinghaiTibetan Plateau, Glob. Change Biol., 12, 1285-1298, 2006.

Kormann, R. and Meixner, F. X.: An analytical footprint model for nonneutral stratification, Bound.-Layer Meteorol., 99, 207-224, 2001.

Liu, J., Zhang, Y., Li, Y., Wang, D., Han, G., and Hou, F.: Overview of grassland and its development in China. Multifunctional grasslands in a changing world volume (I), Guangdong People's Publishing House, Guangzhou, 3-5, 2008.

Liu, X.D. and Chen, B. D.: Climatic warming in the Tibetan Plateau during recent decades, Int. J. Climatol., 20, 1729-1742, 2000.
Lloyd, J. and Taylor, J. A.: On the temperature-dependence of soil respiration, Funct. Ecol., 8, 315-323, 1994.

Moore, C. J.: Frequency response corrections for eddy correlation systems, Bound.-Lay. Meteorol., 37, 17-35, 1986.

Parton, W. J., Scurlock, J. M. O., Ojima, D. S., Schimel, D. S., and Hall, D.O.: Impact of climate change on grassland production and soil carbon worldwide, Glob. Change Biol., 1, 13-22, 1995.

Polley, H. W., Frank, A. B., Sanabria J., and Phillips, R.: Interannual variability in carbon dioxide fluxes and flux-climate relationships on grazed and ungrazed northern mixed-grass prairie, Glob. Change Biol., 14, 1620-1632, 2008.

Richardson, A. D., Hollinger, D. Y., Aber, J. D., Ollinger, S. V., and Braswell, B. H.: Environmental variation is directly responsible for short- but not long-term variation in forest atmosphere carbon exchange, Global. Change Biol., 13, 788-803, 2007.

Shao, J., Zhou, X., He, H., Yu, G., Wang, H., Luo, Y., Chen, J., Gu, L., and Bo, L.: Partitioning climatic and biotic effects on interannualvariability of ecosystem carbon exchange in three ecosystems, Ecosystems, 17, 1186-1201, 2014.

Shi, P. L., Sun, X. M., and Xu, L. L.: Net ecosystem $\mathrm{CO}_{2}$ exchange and controlling factors in a steppe-Kobresia meadow on the Tibetan Plateau, Sci. China-Earth Sci., 49, 207-218, 2006.

Shimoda, S., Mo, W., and Oikawa, T: The effects of characteristics of Asian monsoon climate on interannual $\mathrm{CO}_{2}$ exchange in a humid temperate $\mathrm{C} 3 / \mathrm{C} 4$ co-occurred grassland, SOLA, 1, 169-172, 2005.

Suyker, A. E., Verma, S. B., and Burba, G. G.: Interannual variability in net $\mathrm{CO}_{2}$ exchange of a native tallgrass prairie, Glob. Change Biol., 5, 255-265, 2003.

Teklemariam, T. A., Lafleur, P. M., Moore, T. R., Roulet, N. T., and Humphreys, E. R.: The direct and indirect effects of inter-annual meteorological variability onecosystem carbon dioxide exchange at a temperate ombrotrophic bog, Agr. Forest Meteorol., 150, 1402-1411, 2010.

Vickers, D. and Mahrt, L.: Quality control and flux sampling problems for tower and aircraft data, J. Atmos. Ocean. Technol., 14, 512-526, 1997.

Wang, L., Liu, H. Z., and Bernhofer, C.: Response of carbon dioxide exchange to grazing intensity over typical steppes in a semiarid area of Inner Mongolia, Theor. Appl. Climatol., 127, 1-12, doi:10.1007/s00704-016-1736-7, 2016a.

Wang, L., Liu, H. Z., Sun, J. H., and Feng, J. W.: Water and carbon dioxide fluxes over an alpine meadow in southwest China and the impact of a spring drought event, Int. J. Biometeorol., 60, 195-205, 2016b.

Webb, E. K., Pearman, G. I., and Leuning, R.: Correction of flux measurements for density effects due to heat and water vapour transfer, Q. J. R. Environ. Soc., 106, 85-100, 1980.

Wilczak, J. M., Oncley, S. P., and Stage, S. A.: Sonic anemometer tilt correction algorithms, Bound.-Lay. Meteorol., 99, 127-150, 2001.

Xu, L. K. and Baldocchi, D.: Seasonal variation in carbon dioxide exchange over a Mediterranean annual grassland in California, Agr. Forest Meteorol., 1232, 79-96, 2004.

Yang, F. L. and Zhou, G. S.: Sensitivity of temperate desert steppe carbon exchange to seasonal droughts and precipitation variations in Inner Mongolia, China, PLoS One, 8, e55418, doi:10.1371/journal.pone.0055418, 2013 
Yu, G. R., Fu, Y., Sun, X., Wen, X., and Zhang, L.: Recent progress and future directions of ChinaFLUX, Sci. China-Earth Sci., 49, $1-23,2006$
Zhao, L., Li, Y., Xu, S. Y., Zhou, H. K., Gu, S., Yu, G. R., and Zhao, X. Q.: Diurnal, seasonal and annual variation in net ecosystem $\mathrm{CO}_{2}$ exchange of an alpine shrubland on Qinghai-Tibetan plateau, Glob. Change Biol., 12, 1940-195, 2006. 